\title{
Anaerobic Digestion of Biomass for production of Biogas: Progress and Advantages
}

Kumar Gaurav

Amity Institute of Biotechnology, Amity University Haryana, Gurugram-122413, India

To Cite this Article

Kumar Gaurav, "Anaerobic Digestion of Biomass for production of Biogas: Progress and Advantages", International Journal for Modern Trends in Science and Technology, Vol. 06, Issue 05, May 2020, pp.: 108-111; https://doi.org/10.46501/IJMTST060519

\section{Article Info}

Received on 02-April-2020, Revised on 28-April-2020, Accepted on 10-May-2020, Published on 15-May-2020.

\section{ABSTRACT}

A major share of world's primary energy requirement is dependent on fossil fuels which is not only a non renewable source of energy and on the verge of extinction but also associated with serious environmental concerns. To combat these issues, alternative renewable energy sources are required. Certain examples of renewable energy sources are solar energy, wind energy, hydro and thermal energy, biofuels etc. Biomass is one such alternative which is freely and abundantly available. It is mainly the agricultural waste and vegetable waste which are perishable and create a lot of nuisance. Tapping this biomass for energy production will be beneficial in two ways; it will be an excellent source of energy generation and it will also help in waste management for environment protection. Energy generation from Biomass can take place either chemically or thermo-chemically. In the present paper advantages of anaerobic digestion of biomass are discussed for biogas production.

KEYWORDS: Renewable energy, Anaerobic digestion, Biomethane, Environmental pollution, Feedstock

Copyright (C) 2014-2020 International Journal for Modern Trends in Science and Technology

DOI: https://doi.org/10.46501/IJMTST060519

\section{INTRODUCTION}

Presently, world is facing three major crises; reduction of energy resources, consumption of fossil fuel and environmental pollution, globally. Fossil fuels (coal, oil, petroleum and natural gas) are non-renewable source of energy and provide $80 \%$ of total energy consumption in production of electricity and energy consumption is increasing $2 \%$ per year [1]. Therefore, there is need for clean and renewable energy. Biomass is a renewable source of energy and can replace fossil fuel. Energy generations from biomass are mainly of two types; chemical process (fermentation and anaerobic digestion) and thermochemical process (gasification, combustion, pyrolysis). The heat loss is $20 \%$ in combustion and $30 \%$ in gasification due to moisture content in biomass, therefore, biological conversion is most suitable. Biogas is inexpensive and flammable renewable source of energy produced by anaerobic digestion of biodegradable organic matter and could be a potential substitute for fossil fuel. It will reduce green house gas emission and decrease dependence on imported fuel. Anaerobic digestion (AD) is breakdown of organic matter (plant biomass, animal manure, agricultural residue and waste water treatment sludge) in absence of oxygen to produce methane rich gas and it is mediated by thermophillic and mesophillic microorganism. It is mainly composed of $\mathrm{CH}_{4}(55-80 \%), \mathrm{CO}_{2}(20-45 \%)$, $\mathrm{H}_{2}$ (5-10\%) with small amount of moisture and siloxanes. Biomethane is upgraded form of biogas 
and typically composed of $\mathrm{CH}_{4}(97 \%)$ and $\mathrm{CO}_{2}(3 \%)$. The presence of methane and carbon dioxide make its combustible and can be used as a fuel while presence of hydrogen sulfide (10-30 to 500-2000 ppm depends on feedstock in digestion) make its toxic, corrosive to engine and metal parts. Raw biogas $(1 \mathrm{~m} 3)$ at standard temperature and pressure containing $60 \% \mathrm{CH}_{4}$ has a heating value of $21.5 \mathrm{MJ}$ (5.97 $\mathrm{Kwh}$ of electricity equivalent). Combustion of biogas result in zero carbon dioxide emission and reduces the pollutant gas $\mathrm{NO}_{\mathrm{X}}$ and $\mathrm{SO}_{2}$

\section{WORLD SCENARIO OF BIOGAS PLANT}

Germany is pioneer, largest producer of biogas and have 8000 agricultural biogas plant units were in operation. It produces 6716 tonne of biogas in 2013 and have major contribution to European Biogas market [2, 3]. In, India (3 million biogas plant), Sweden (20 biogas plant), Austria (90 biogas plant), Turkey (800 biogas plant) produces biogas from agricultural waste, sewage sludge, animal manure and food waste. The other countries; UK, Italy, France and Netherlands produced 1824, 1815, 465 and 302 tonne respectively in 2013.

\section{STEPS IN BIOGAS PRODUCTION}

Biogas is produced by complex process and involving four phases ; (i) hydrolysis, (ii) acidogenesis , (iii) acetogenesis and (iv) methanogenesis using different group of bacteria. In hydrolysis, complex organic matters (polysaccharide, protein, lipid) are hydrolyzed into simple organic monomers respectively (sugar, amino acids and fatty acid). This process is facilitated by fermentative and hydrolytic bacteria such as Clostridium, Bacillus, Acetovibrio, Ruminococcus, Bacteriodes, Thermomonosporu and Microbispora. They releases extracellular enzyme and hydrolyzed organic matters. It is rate limiting step for highly solid feedstock and process can be improved by pretreatment of organic matters. During acidogenesis, monomers and oligomers are fermented by Lactobacillus, Bacillus, Streptococcus, and Escherichia into volatile fatty acids (butyric acid, propoinic acid), alcohol, carbon dioxide and hydrogen. In this step, large amount of carbon dioxide and hydrogen are produced and if feedstocks have high carbohydrate content, hydrogen production will be high and it can be harvested and used as biofuel. In acetogenesis; volatile fatty acid and alcohol are oxidized into acetate, $\mathrm{CO} 2$ and $\mathrm{H} 2$ by homoacetogens
(Clostridium, Acetobacterium, Syntrophosphora, Thermosyntropha, Syntrophomonas, Eubacterium). Homoacetogens are also known as hydrogen-oxidizing acteogenic bacteria and have long doubling time.

Methanogenesis is the final stage of anaerobic digestion and it is mediated by three different pathways ; (i) aceticlastic pathway (utilize acetate as a substrate), (ii) $\mathrm{CO} 2$ reduction (Wood Ljungdahl) pathway and (iii) methylotrophic pathway. These pathways are differentiated by energy source and nature of feedstock. Methane content depends on organic content in substrate. The seventy percent of methane is originated by decarboxylation of acetate while remain is produced by reduction of $\mathrm{CO} 2$ [4]. Methanococcus, Methanosarcina, and Methanolobus are mainly responsible for methanogenesis and it is rate-limiting step for highly soluble feedstock. The byproduct of anaerobic digestion called as digestate and can be used as a biofertilizer for crop cultivation.

\section{BENEFITS OF BIOGAS}

Biogas, cheapest and alternative source of fossil fuel, can be used in heating, cooking, steam generation, electricity production, transportation fuel (upgraded biogas) and lighting [5, 6]. The use of biogas for energy production could displace fossil fuel, reduce green house emission and decrease the dependence on fossil fuel. In 2012, the biogas usage was 14.5 gigawatts (GW) and it will be double $(29.5 \mathrm{GW})$ in $2022[7,8]$. About $45 \%$ of world population depends on cattle dung, coal, crop residue, firewood to meet their energy needs for cooking and $20 \%$ of world population have not electrical grid connection. In developing countries, biogas is primarily used for cooking and lighting purposes because the average size of digester is $2-10 \mathrm{~m} 3$. The biogas produced by this digester cannot be purified into biomethane as well as cannot be used in combined heat and power generation (CHP). In India, total energy consumption for cooking is $60 \%$ [9]. Another use of biogas is lighting in mantle lamps especially in areas of without electrical power.

\section{HEALTH BENEFITS}

Crop residue, animal dung, charcoal, fuel woods are used for cooking purpose in rural area. Burning of the biomass in cook stoves releases high amount of carbon monoxide, hydrocarbons and particulate matters [10] and results in severe 
health issue due to indoor air pollution (IAP). IAP causes 1.3 million premature death every year and reduces productive life years by $5 \%$ [11,12] in India . IAP is linked with several health problems such as lung cancer, tuberculosis [13], high blood pressure, asthma and cataracts [14], low birth weight, child pneumonia, chronic obstructive pulmonary disease. Women and children are severely affected by IAP because they are involved in cooking and prolonged exposure to smoke. Biogas, clean and provide smoke-free environment. IAP linked disease can be lowered by widespread installation and use of biogas.

\section{ENVIRONMENTAL BENEFITS}

The use of fuel wood for energy purpose causes $54 \%$ of deforestation. The major reason for soil erosion and land degradation is deforestation. Therefore, use of biogas can significantly reduce deforestation.

\section{SOCIAL BENEFITs}

For cooking food, women and children are responsible for collection of fire woods and dung in developing countries. Both of these are time consuming ( 6 hours a day) and tedious work (travel more than $5 \mathrm{~km}$ per day) $[15,16]$ and in results in lead to IAP linked disease as well as back and neck pain [17]. Because of these, women and children are deprived for education, social work, income-generating labor and recreational activities. Therefore, there is need for installation of biogas plant at household level and it provides better opportunities for education and other activities.

\section{FEEDSTOCK FOR BIOGAS PRODUCTION}

Biomass contains carbohydrates, proteins and fats, which can be used as feedstock for biogas production. Carbohydrates and proteins shows faster conversion rates than fats and provides higher yield of biogas. There are different feedstocks can be utilized for biogas production such as lignocellulosic waste, animal manure, municipal solid waste and sewage waste. Lignocellulosic waste (agricultural residues and energy crop) are considered as potential feedstock for large-scale biogas production [19]. Lignocellulose consist of three main components: cellulose $(30-50 \%)$, hemicellulose $(15-35 \%)$ and lignin $(10-20 \%) \quad[19,20]$. Cellulose and hemicellulose are linked to lignin through covalent and hydrogen bond and makes it resistant to any treatment. These components form crystalline structure by physical and chemical association, which is difficult to be utilized by anaerobic bacteria to produce biogas. Pretreatment methods are necessary to breakdown the crystal structure and enhance utilization efficiency. To increase biogas production from lignocellulosic mass, pretreatment methods include physical, physico-chemical, chemical, biological and combined approaches can be used.

\section{Conclusion}

In the quest of certain renewable source of energy, Biomass emerged as a viable option because of its abundance and availability. In recent years, anaerobic digestion of biomass has drawn attention mainly for degrading agricultural and vegetable waste because of several advantages associated with it. It results in generation of biogas as fuel and the effluents released can be used as natural fertilizers. It also controls environmental pollution by treating the waste in an eco-friendly manner. It is energy efficient process, thus contributes in green chemistry.

\section{REFERENCES}

[1] Mason J E (2007). World Energy analysis: H2 now or later. Energy Policy. 35:1315-1329.

[2] Fusi A, Bacenetti J, Fiala M, Azapagic A (2016) Life cycle environmental impacts of electricity from biogas produced by anaerobic digestion. Frontiers in Bioengineering and Biotechnology. $4: 1-17$.

[3] Sorda G, Sunak Y, Madlener R (2013). An agent-based spatial simulation to evaluate the promotion of electricity from agricultural biogas plants in Germany. Ecological Economics. 89: 43-60.

[4] Zieminski K,FracM (2012) Methane fermentation process as anaerobic digestion of biomass: transformations, stages and microorganisms. African Journal of Biotechnology. 11:4127-4139.

[5] Mata AJ, Cecchi F, Llabres P, Pavan P (1992). Anaerobic digestion of the Barcelona Central food market organic wastes: experimental study. Bioresource Technology. 39: 39-48.

[6] Ahring BK, Mladenovska Z, Iranpour R, Westermann P (2002). State of the art and future perspectives of thermophilic anaerobic digestion. Waste Science and Technology. 45:298-308.

[7] Maroneze MM, Zepka LQ, Vieira JG, Queiroz MI, Jacob-Lopes E (2014). Production and use of biogas in Europe: a survey of current status and perspectives. Rev Ambient E Agua. 9:445-458.

[8] Kárászová M, Sedláková Z, Izák P (2015). Gas permeation processes in biogas upgrading: a short review. Chemical Papers. 69:1277-1283.

[9] Ravindranath NH, Hall DO (1995). Biomass, energy and environment - a developing country perspective from India. 
Oxford :Oxford UniversityPress; 1995.

[10] Smith KR, Samet JM,Romieu I,BruceN (2002). Indoor air pollution in developing countries and acute lower respiratory infections in children. Thorax. 5: 518-532.

[11] Rohra H, A. Taneja A (2016).Indoor air quality scenario in India- an outline of household fuel combustion, Atmospheric Environment. 129: 243-255.

[12] Reddy BS, T. Srinivas T (2009). Energy use in Indian household sector - an actor-oriented approach. Energy. 34: 992-1002.

[13] Salma K, Chiang CY, Hinderaker SG, Bruce NG,Vedal S,Enarson DA (2010). Indoor solid fuel combustion and tuberculosis: is there an association?. The international journal of tuberculosis and lung disease. 14: 6-14.

[14] Bruce N, Perez-PadillaR, Albalak R (2000). Indoor air pollution in developing countries: a major environmental and public health challenge. Bulletin of the World Health Organization. 78: 1078-1092.

[15] Topa N, MizoueN, KaibS, Nakao T (2004). Variation in woodfuel consumption patterns in response to forest availability in Kampong Thom Province, Cambodia. Biomass and Bioenergy. 27: 57-68.

[16] Liua G, LucasM,ShenL(2008). Rural household energy consumption and its impacts on eco-environment in Tibet: Taking Taktse county as an example. Renewable and Sustainable Energy Reviews. 12: 1890-1908.

[17] Gautam R, Baral S, Heart S (2009). Biogas as a sustainable energy source in Nepal: Present status and future challenges. Renewable and Sustainable Energy Reviews. 13: 248-252.

[18] Li K, Liu RH, Sun C (2016). A review of methane production from agricultural residues in China. Renewable and Sustainable Energy Reviews. 54:857-865.

[19] Iqbal HMN, Ahmed I, Zia MA, Irfan M (2011). Purification and characterization of the kinetic parameters of cellulase produced from wheat straw by Trichoderma viride under SSF and its detergent compatibility. Advances in Bioscience and Biotechnology. 2 :149-156.

[20] Kumar P, Barrett DM, Delwiche MJ, Stroeve P (2009). Methods for pretreatment of lignocellulosic biomass for efficient hydrolysis and biofuel production. Industrial and Engineering Chemistry and Research.48 :3713-3729

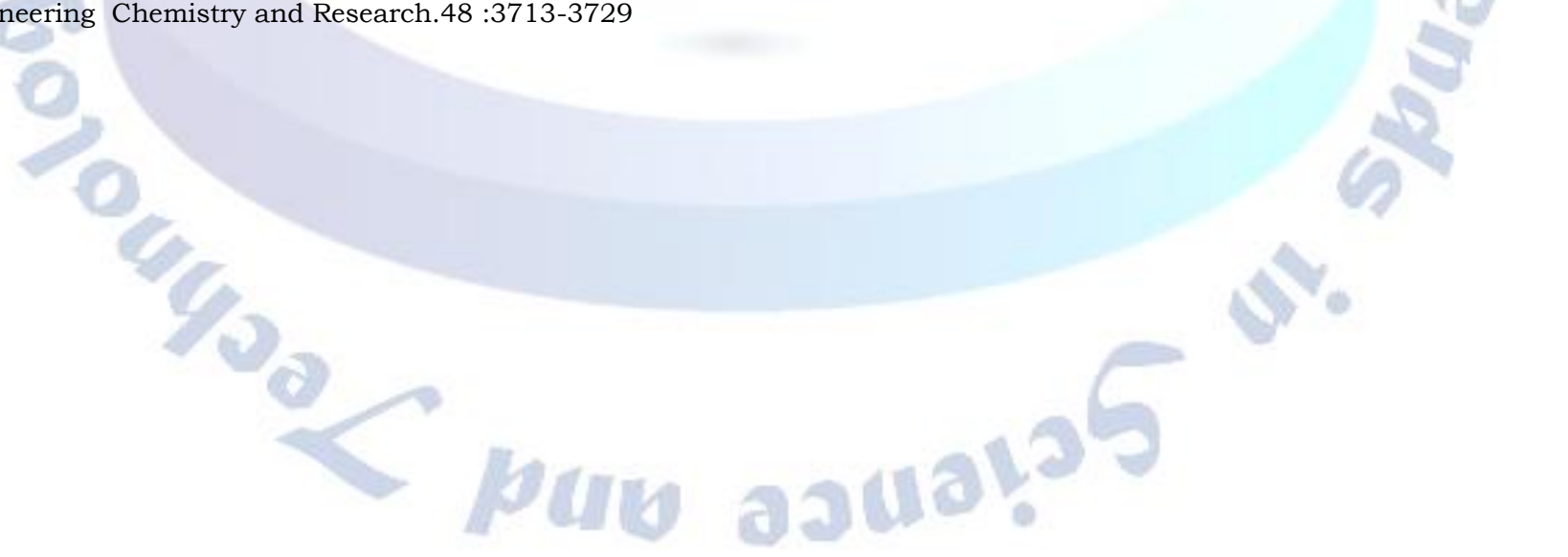

